\begin{tabular}{|c|c|c|c|}
\hline $\begin{array}{c}\text { Case Reports in } \\
\text { Cicisis }\end{array}$ & $\begin{array}{l}\text { Case Rep Oncol 2011;4:39-43 } \\
\text { DOI: } 10.1159 / 000324405\end{array}$ & $\begin{array}{l}\text { Published online: } \\
\text { January } 29,2011\end{array}$ & $\begin{array}{l}\text { O } 2011 \text { S. Karger AG, Basel } \\
\text { ISSN } 1662-6575 \\
\text { www.karger.com/cro }\end{array}$ \\
\hline
\end{tabular}

\title{
Thyroglossal Duct Cyst Papillary Carcinoma
}

\author{
N. Balalaa ${ }^{a} \quad$ M. Megahed ${ }^{a} \quad$ M. Al Asharib ${ }^{b}$ Franickia, \\ Departments of a Surgery and bPathology, Tawam Hospital in Affiliation with \\ Johns Hopkins Medicine, and ' Faculty of Medicine and Health Sciences, United \\ Arab Emirates University, Al Ain, United Arab Emirates
}

\section{Key Words}

Thyroglossal cyst · Papillary carcinoma $\cdot$ Thyroid

\begin{abstract}
Thyroglossal duct cysts are usually located in the midline of the neck. The coexistence of carcinomas in thyroglossal duct cysts is extremely rare, with most being papillary carcinomas. Usually, the diagnosis is only made postoperatively after excision of the cyst. Although the Sistrunk procedure is often regarded as adequate, controversies exist concerning the need for thyroidectomy depending on histopathological findings. We report the case of a 31-year-old man diagnosed with papillary carcinoma within a thyroglossal duct cyst, who underwent total thyroidectomy as has been recommended for differentiated papillary cancer.
\end{abstract}

\section{Introduction}

The thyroid gland descends from the foramen cecum to its location at the point below the thyroid cartilage. It leaves behind an epithelial tract known as the thyroglossal tract; this tract usually disappears during the 5th-10th gestational weeks. Incomplete atrophy of the thyroglossal tract or retained epithelial cysts, however, create the basis for the origin of a thyroglossal duct cyst (TGDC). A thyroglossal remnant may be a cyst, a tract or duct, a fistula, or an ectopic thyroid within a cyst or duct. Failure of this tract to close predisposes to the formation of a thyroglossal cyst [1].

A TGDC is the most common anomaly in the development of the thyroid gland [2]. Seventy percent of midline masses diagnosed during childhood and 7\% in adults are TGDCs [3]. Only 1\% of thyroid carcinomas arise from a TGDC [4]. Brentano in 1911 and Uchermann in 1915 are credited as being among the first to describe a neoplasm in a thyroglossal duct (TGD) remnant; the median age at presentation is 40 years and most patients are asymptomatic (cited by Weiss and Orlich [5]).

Definitive surgical management requires excision not only of the cyst but also of the path's tracts and branches. The strong association between the tract and the hyoid bone 
requires the simultaneous removal of the central portion of the hyoid bone to ensure the complete removal of the tract (Sistrunk procedure). Recurrence is unlikely, except in cases with skin involvement or intraoperative cyst rupture.

There is still controversy regarding the need to remove the thyroid gland in the case of a papillary carcinoma of the TGD [4]. Thyroidectomy is recommended in cases where (a) the thyroid gland is found to be nodular, with a cold nodule in a thyroid iodine uptake scan; (b) enlarged lymph nodes are present, or (c) a history of neck irradiation exists [6].

\section{Case Report}

A 31-year-old man was referred to our center with a TGD papillary carcinoma $(12 \times 10 \mathrm{~mm})$ diagnosed histopathologically after a Sistrunk operation 1 month earlier. Clinically, the thyroid was not enlarged and no cervical lymph node enlargement was palpable. We reviewed the slides to confirm the diagnosis (fig. 1, fig. 2, fig. 3). Thyroid function tests were normal and a thyroid ultrasound showed a lesion at the posterior aspect of the lower pole of the left lobe, measuring $12 \times 8 \mathrm{~mm}$, with a predominantly echogenic stroma and two areas of calcification. No lymph node enlargement was identified in the neck. The patient underwent total thyroidectomy and the examination of the frozen section of the biopsied cervical lymph nodes revealed no malignancy. Histopathology of the thyroid demonstrated benign follicular nodules. Postoperatively, the iodine-131 $\left(\mathrm{I}^{131}\right)$ uptake scan revealed two spots of activity in the thyroid bed. The patient was treated with radioactive iodine and subsequently commenced thyroid hormone suppression therapy.

\section{Discussion}

TGDCs are the most common congenital anomalies in thyroid development, but TGD carcinomas are extremely rare, with $90 \%$ of them originating from thyroid remnants [5]. Papillary types comprise $94 \%$, and less than $5 \%$ are of squamous cell origin [7]. Their cause is unknown and there are no predisposing factors, i.e. neither clinical history nor physical examination can lead to a preoperative diagnosis [8].

Generally, there are two theories to explain the thyrogenic origin of TGD adenocarcinomas. Firstly, the de novo theory is based on the fact that in $62 \%$ of cases, ectopic thyroid tissue can be identified histopathologically, and this is supported by the absence of a medullary carcinoma in the TGD as it arises from parafollicular cells [9].

The second is the metastatic theory which suggests that thyroglossal cyst carcinoma is metastatic from an occult primary thyroid gland, as papillary carcinoma is multifocal in nature [10]. Although Crile [11] believed that the TGD could act as a natural conduit for the spread of thyroid carcinoma, the metastatic theory seems less likely [12]. Mobini et al. [13] concede that squamous cell carcinoma is probably the only true carcinoma of the TGD, since the other malignancies actually develop in ectopic thyroid tissue. Thus, squamous cell carcinoma can be considered the only primary thyroglossal cyst tumor, being very rare and having a poor prognosis with a mortality rate of $30-40 \%$ [14].

Multicentricity and multifocal growth are common in papillary thyroglossal carcinomas, as a second malignant lesion is present in $10 \%$ of cases with thyroid cancer [5]. Conservative management of papillary thyroid cancer is indicated only in low-risk patients who are female and younger than 40 years old, with no invasion of the capsule and a low-grade tumor of less than $1 \mathrm{~cm}$ in size. We recommend no additional treatment to the Sistrunk procedure for pure thyroglossal carcinoma of squamous cell origin. In 
contrast, for differentiated thyroid malignancy in a thyroglossal cyst, total thyroidectomy is indicated, whether or not the thyroid is involved clinically or radiologically. In the case of large tumors $>1 \mathrm{~cm}$, invasion through the duct cyst wall or suspect foci in the thyroid gland, a total thyroidectomy followed by $\mathrm{I}^{131}$ ablation and thyroid-stimulating hormone suppression is the most frequently proposed treatment [15]. Thyroidectomy aids staging and can facilitate the detection of metastases and recurrence using radioactive iodine because of multicentricity in the papillary carcinoma subtype. Regarding cervical lymph nodes, even if these are not palpable, clinically frozen sections are considered to be mandatory. Radical or modified radical neck dissection is indicated only in the presence of positive lymph nodes [5]. The risk of injury to the recurrent laryngeal nerve or parathyroid glands in skilled hands is very uncommon, and the highest risk of injury occurs in redo surgery.

\section{Conclusion}

The diagnosis of TGD carcinoma can be missed due to its rarity. For rapidly growing midline neck masses, relevant investigations involving imaging of the neck and fineneedle aspiration cytology are required. The Sistrunk operation alone is sufficient for squamous carcinoma, but total thyroidectomy is recommended for differentiated thyroid carcinoma.

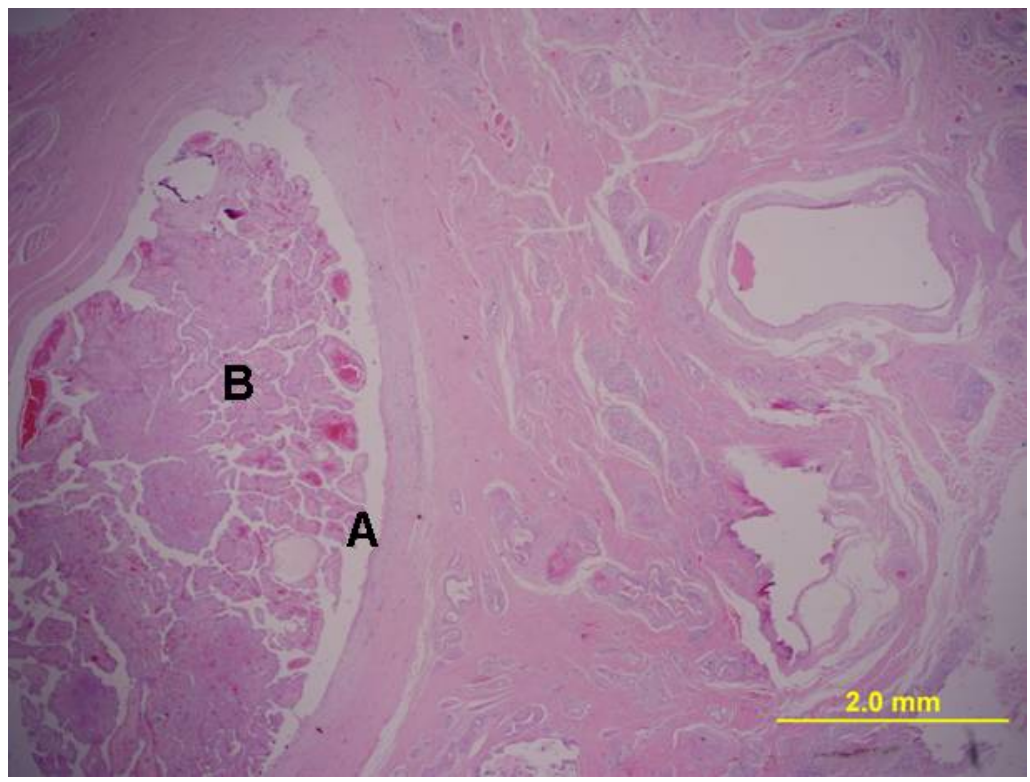

Fig. 1. TGDC wall (A). Papillary tumor inside the cyst (B). 


\begin{tabular}{|c|c|c|c|}
\hline $\begin{array}{c}\text { Case Reports in } \\
\text { Cicis: }\end{array}$ & \begin{tabular}{|l} 
Case Rep Oncol 2011;4:39-43 \\
DOI: 10.1159/000324405
\end{tabular} & $\begin{array}{l}\text { Published online: } \\
\text { January 29, } 2011\end{array}$ & $\begin{array}{l}\text { O } 2011 \text { S. Karger AG, Basel } \\
\text { ISSN 1662-6575 } \\
\text { www.karger.com/cro }\end{array}$ \\
\hline
\end{tabular}

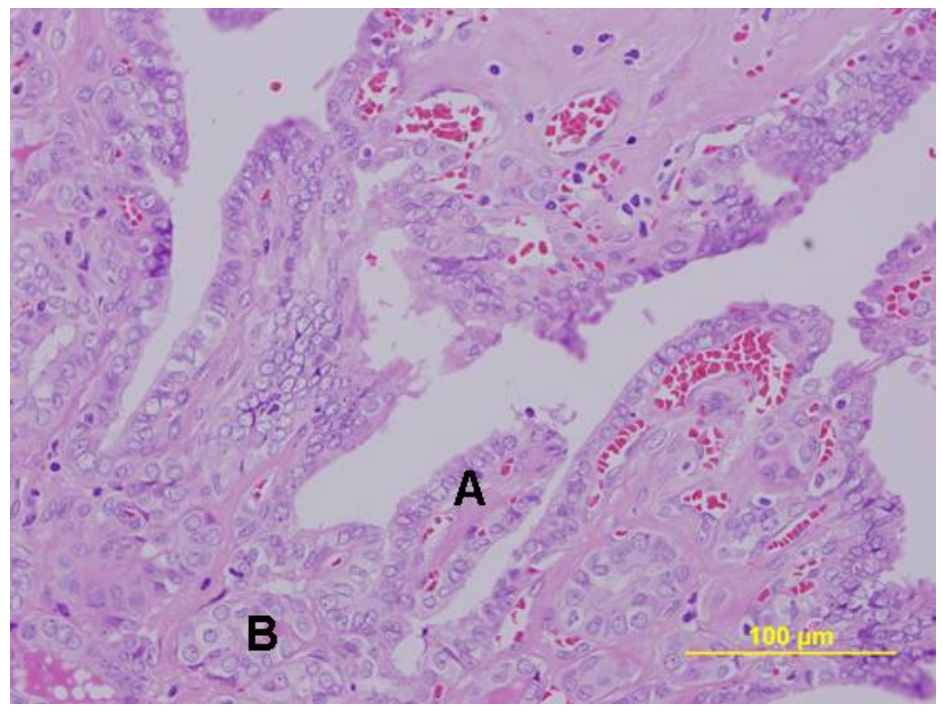

Fig. 2. The growth of the tumor with a papillary (A) and a follicular (B) pattern.

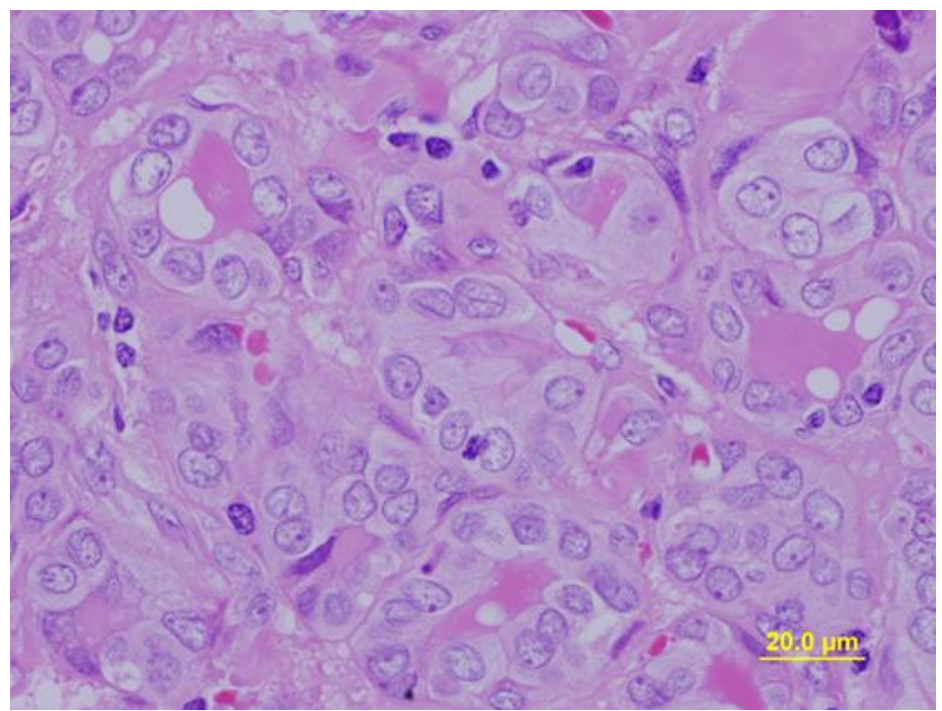

Fig. 3. Nuclear features of the tumor showing overcrowding of the nuclei with nuclear grooving and intranuclear pseudoinclusion. 


\section{References}

1 Peretz A, Leiberman E, Kapelushnik J, Hershkovitz E: Thyroglossal duct carcinoma in children: case presentation and review of the literature. Thyroid 2004;14:777-785.

2 Vera-Sempere F, Tur J, Jaén J, Perolada JM, Morera C: Papillary thyroid carcinoma arising in the wall of a thyroglossal duct cyst. Acta Otorhinolaryngol Belg 1998;52:49-54.

-3 Yang YJ, Haghir S, Wanamaker JR, Powers CN: Diagnosis of papillary carcinoma in a thyroglossal duct cyst by fine-needle aspiration biopsy. Arch Pathol Lab Med 2000;124:139-142.

4 Dedivitis RA, Guimarães AV: Papillary thyroid carcinoma in thyroglossal duct cyst. Int Surg 2000;85:198-201.

5 Weiss SD, Orlich CC: Primary papillary carcinoma of a thyroglossal duct cyst: report of a case and literature review. Br J Surg 1991;78:87-89.

6 Kazemi M, Assadi M, Kazemi AA, Ghazvini LA: Primary papillary carcinoma in a thyroglossal duct cyst. Hell J Nucl Med 2006;9:39-40.

7 Wexler MJ: Surgical management of thyroglossal duct carcinoma: is an aggressive approach justified? Can J Surg 1996;39:263-264.

$\checkmark 8$ Buchino JJ, Fallat ME, Montgomery VL: Pathological case of the month: papillary carcinoma of the thyroid in a thyroglossal duct remnant. Arch Pediatr Adolesc Med 1999;153:999-1000.

$\checkmark 9$ Hilger AW, Thompson SD, Smallman LA, Watkinson JC: Papillary carcinoma arising in a thyroglossal duct cyst: a case report and literature review. J Laryngol Otol 1995;109:1124-1127.

10 Tew S, Reeve TS, Poole AG, Delbridge L: Papillary thyroid carcinoma arising in thyroglossal duct cyst: incidence and management. Aust NZ J Surg 1995;65:717-718.

-11 Crile G Jr: Papillary carcinoma of the thyroid and lateral cervical region; so called lateral aberrant thyroid. Surg Gynecol Obstet 1947;85:757-766.

12 Kennedy TL, Whitaker M, Wadih G: Thyroglossal duct carcinoma: a rational approach to management. Larynogoscope 1998;108:1154-1158.

13 Mobini J, Krouse TB, Klinghoffer JF: Squamous cell carcinoma arising in a thyroglossal duct cyst. Am Surg 1974;40:290-294.

14 Boswell WC, Zoller M, Williams JS, Lord SA, Check W: Thyroglossal duct carcinoma. Am Surg 1994;60:650655.

15 Kristensen S, Juul A, Moesner J: Thyroglossal cyst carcinoma. J Laryngol Otol 1984;98:1277-1280. 